\title{
CLT Fabricated with Gmelina arborea and Tectona grandis Wood from Fast-Growth Forest Plantations: Physical and Mechanical Properties
}

\author{
Freddy Muñoz ${ }^{1}$, Carolina Tenorioo ${ }^{1}$, Róger Moya ${ }^{1,+}$ and Angel Navarro-Mora ${ }^{2}$ \\ ${ }^{1}$ Escuela de Ingeniería Forestal, Instituto Tecnológico de Costa Rica, Cartago, 159-7050, Costa Rica \\ ${ }^{2}$ Escuela de Ingeniería en Construcción, Instituto Tecnológico de Costa Rica, Cartago, 159-7050, Costa Rica \\ *Corresponding Author: Róger Moya. Email: rmoya@itcr.ac.cr
}

Received: 07 May 2021 Accepted: 02 June 2021

\begin{abstract}
Fabrication and use of Cross Laminated Timber (CLT) using tropical woods is still limited at present. Therefore objective of the present study aims to determine the possibility of using CLT panels of 3 and 5 layers, fabricated with Tectona grandis and Gmelina arborea wood using adhesive of isocyanate polymer emulsion system catalyzed with polymeric isocyanate. Delamination, water absorption, density, flexure test, compression and glue-line shear were evaluated using ANSI/APA PRG320-2012 ASTM D198 and ASTM D4761 standard. The results showed that CLT panels of T. grandis presented higher values of density, less water absorption and lower delamination, with no evident differences between the CLT of 3 and 5 layers. The high density of T. grandis resulted in higher values of the mechanical properties. The flatwise and edgewise flexure tests in 5-layer CLT panels of both species presented higher values of bending stiffness compared to those of 3-layer CLT panels. Further the bending stress values in 3-layer CLT panels were higher than for 5-layer CLT panels. As for shear stress in bending flatwise, in both species, 3-layer CLT surpassed 5-layer CLT panels, but in the edgewise test no differences were observed. The MOE and $\mathrm{Fc}$ in the compression test were superior in relation to the edgewise test. MOE and Fc in compression flatwise in 3-layer CLT was greater than in 5-layer CLT in both species, but edgewise these values were higher in 5-layer CLT panels. The most common failures were stress and delamination in the flexure test, whereas in the compression test these were: shearing, splitting and crushing. In the glue-line shear test no differences were observed between CLT panels of 3 and 5 layers for both species.
\end{abstract}

\section{KEYWORDS}

Structural elements; sustainable material; building material; tropical wood; wood of plantation

$\begin{array}{ll}\text { Abbreviations } \\ \text { CLT: } & \text { cross laminated timber } \\ \text { WA: } & \text { water absorption } \\ \text { MC: } & \text { moisture content } \\ \text { FV: } & \text { shear stress in bending } \\ \text { Fb: } & \text { bending stress } \\ \text { Fc: } & \text { module of rupture in compression test } \\ \text { EI: } & \text { bending stiffness } \\ \text { MOE: } & \text { module of elasticity }\end{array}$

This work is licensed under a Creative Commons Attribution 4.0 International License, which permits unrestricted use, distribution, and reproduction in any medium, provided the original work is properly cited. 


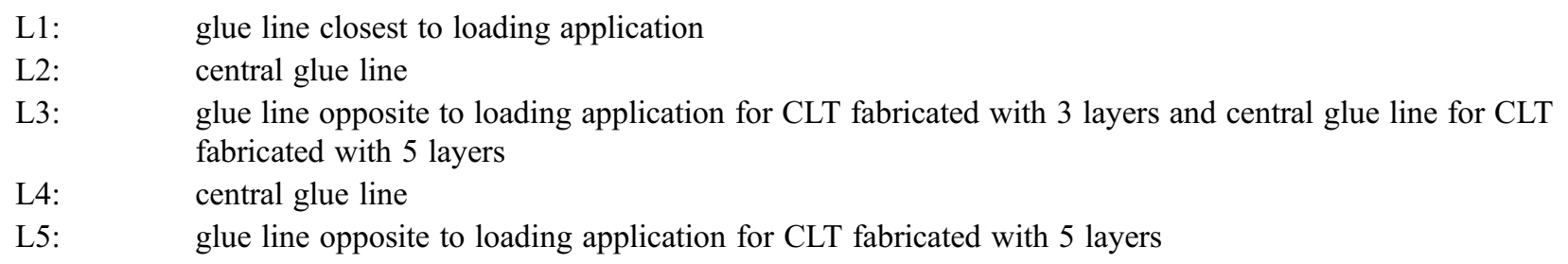

\section{Introduction}

Cross-laminated timber (CLT) is an innovative engineering product in the form of a laminated structure fabricated with timber boards placed in 3,5 or 7 layers [1] and they can be fabricated with solid wood or bamboo [2]. The timber boards are adjacent and superposed with adhesive at an angle of $90^{\circ}$ [1]. This product has excellent physical and mechanical properties as construction material [3] and hardwood species present good properties to be used in this product [4]. As such, CLT is frequently used in panels for flooring, roofing and walls and low to mid-rise constructions because of its high rigidity and support capability in the parallel and perpendicular planes [5]. In addition, CLT presents favorable aesthetic, energy, and environmental properties, such as carbon dioxide sequestration [1,6]. CLT was developed in Europe during the 1970s; since then it has been manufactured by many species and softwood is used in many countries [7-9].

Furthermore, cross laminating used in CLT panels grants improved dimensional stability, reduces the dispersion of the wood's properties and reduces the influence of the defects, while increasing rigidity in the parallel and perpendicular planes [10]. Compared to other construction materials, CLT panels offer good seismic resistance [11], diminish assembling time [12] and allow the application of fire retardant treatments [13] or treatments to avoid damage due to fungi or insects [14].

The use of CLT panels in the industry and the study of their properties in countries like the United States of America, Canada, Europe, China, Japan, Australia, New Zealand and other temperate countries is widely developed [15]. Accordingly, abundant information is available on the properties of different types of CLT panels made from Pinus, Larch and Spruce [4,6,16,17].

Regarding the different species used in CLT panel construction, the standard for performance-rated cross-laminated timber in its denomination ANSI/APA PRG320-2012 [18] suggests using conifer wood with a minimum 0.35 specific weight, while in Europe, species with densities above $0.42 \mathrm{~g} \mathrm{~m}^{-3}$ are used [19]. More recently, low-added-value timber has been used in CLT panel construction $[4,20]$.

The use of tropical species for CLT panel construction is still limited [21]. However, there are important reports from Malaysia [22] and Brazil [23,24]. The properties of CLT panels of Falcataria moluccana, Anthocephalus macrophyllus, Acacia magnium, hybrid acacia (A. mangium $\times$ A. auriculiformis), Paraserianthes falcataria, Endospermum malaccensis, Hevea brasiliensis, Canarium sp., Intsia bijuga, plus several eucalyptus species, have been studied [22,25-28].

Tectona grandis is used in commercial reforestation in Latin America [29,30], while Gmelina arborea is widely used in Central America [31]. This specie, as G. arborea, are important in Costa Rica market, however their structural uses are limited [32]. Currently, many industries present the conditions and the capacity for the development of innovative products fabricated with wood from forest plantations in Costa Rica, which can be implemented in the construction sector, specifically in the development of structural elements [33]. These industries can promote the development of engineering products fabricated with wood from plantation species, thus increasing the use of their species [32]. 
The CLT panel production from G. arborea and T. grandis wood in Costa Rica is still limited to glulam, I-joint, trusses and plywood and LVL panels [32]. So far, studies on CLT panels have been limited to T. grandis. Triwibowo et al. [34] presented the values obtained for 3-layer CLT panels of T. grandis indicating that these meet the Japan JAS 1152 standard. On the other hand, Byeon et al. [27] showed the flexure results of 3-layer CLT panels of $T$. grandis compared to other tropical and Korean species, stating that the values of resistance of CLT panels are surpassed by Intsia bijuga wood but still comply with Korean standards.

Initially, it is extremely important to develop research, tests, designs and the creation of commercial products such as CLT panels to facilitate the manufacturing process, the selection and the use of raw materials from forest plantations in Costa Rica [26]. Thus, the objective of this research is to determine the appropriateness of CLT panels of 3 and 5 layers fabricated with Tectona grandis and Gmelina arborea woods from forest plantations for structural uses, by evaluating the physical and mechanical properties, such as delamination, water absorption, thickness swelling, moisture content, density, bending flatwise and bending edgewise in flexure test, compression parallel to the grain, and glue line shear test.

\section{Material and Methods}

\subsection{Origin and Characteristics of the Wood}

T. grandis timber was used from trees of 15-years-old growing in La Cruz, Provence of Guanacaste in Costa Rica Costa Rica, and G. arborea approximately 10-years-old from Pérez Zeledón, San José, Costa Rica, both from forest plantations were used. 600 boards with dimension of $25 \mathrm{~mm} \times 100 \mathrm{~mm} \times$ $2500 \mathrm{~mm}$ without planner in green moisture content were used for each specie. The boards were dried and conditioned at $12 \%$ equilibrium content. Then, the boards were planned to $95 \mathrm{~mm}$ in wide and $19 \mathrm{~mm}$ in thickness. Wood properties are detailed in Tab. 1.

Table 1: Values of strength static bending and compression parallel to fiber for G. arborea and T. grandis lumber utilized in the construction in CLT panels [35]

\begin{tabular}{|c|c|c|c|c|c|c|}
\hline \multirow[t]{2}{*}{ Species } & \multicolumn{2}{|c|}{ Static bending } & \multirow{2}{*}{$\begin{array}{l}\text { Compression } \\
\text { parallel to fiber } \\
\begin{array}{l}\text { Maximum } \\
\text { stress }(\mathrm{MPa})\end{array}\end{array}$} & \multirow{2}{*}{$\begin{array}{l}\text { Moisture } \\
\text { content } \\
(\%)\end{array}$} & \multirow{2}{*}{$\begin{array}{l}\text { Specific } \\
\text { gravity }\end{array}$} & \multirow{2}{*}{$\begin{array}{l}\text { Density at } \\
12 \%\left(\mathrm{~kg} / \mathrm{m}^{3}\right)\end{array}$} \\
\hline & $\begin{array}{l}\text { MOE } \\
(\mathrm{GPa})\end{array}$ & $\begin{array}{l}\text { MOR } \\
(\mathrm{MPa})\end{array}$ & & & & \\
\hline G. arborea & $8.14(18.5)$ & $49.30(20.8)$ & $31.19(23.3)$ & 12.0 & $0.45(14.1)$ & $480(19.8)$ \\
\hline T. grandis & $12.84(36.7)$ & $93.26(8.5)$ & $41.67(11,7)$ & 12.0 & $0.57(7.0)$ & $630(4.8)$ \\
\hline
\end{tabular}

Note: $\mathrm{MOE}=$ modulus of elasticity; $\mathrm{MOR}=$ modulus of rupture. Values between parentheses correspond to the coefficient of variation for the given variable.

\subsection{CLT Panels Fabrication}

Wide details on the fabrication of CLT panels are presented in Moya et al. [35]. Furthermore, CLT panels measuring $1150 \mathrm{~mm}$ wide and $2400 \mathrm{~mm}$ long in 2 thicknesses were built: 3 layers, total thickness of $57 \mathrm{~mm}$, and 5 layers, a total thickness of $95 \mathrm{~mm}$ (Fig. 1a) with G. arborea and T. grandis wood. Subsequently, CLT panels were labeled as 3-layer CLT panel and 5-layer CLT panel. In total, 20 panels were constructed ( 2 thickness $\times 2$ species $\times 5$ panels). The adhesive used was isocyanate polymer emulsion systems (Advantage EP'950A ${ }^{\circledR}$ adhesive) catalysed with polymeric isocynate (Franklin ${ }^{\circledR} 200$ catalyst). Both products fabricated for Franklin Adhesives and Polymers (OHIO, USA). The adhesive was applied to one surface of each boards a grammage of $200 \mathrm{~g} \mathrm{~m}^{-2}$ using micropore rollers. After, The boards were located on plate of hydraulic press (model ITALPRESSE PL/)/SCF/8, Italpresse S.A., Bergano, Italy) and was 
applied a pressure of $8.0 \mathrm{MPa}$ during $3600 \mathrm{~s}$. The final size was $1220 \mathrm{~mm}$ wide and $2400 \mathrm{~mm}$ long with different panels thickness. The panels were maintained at $12 \%$ moisture content.
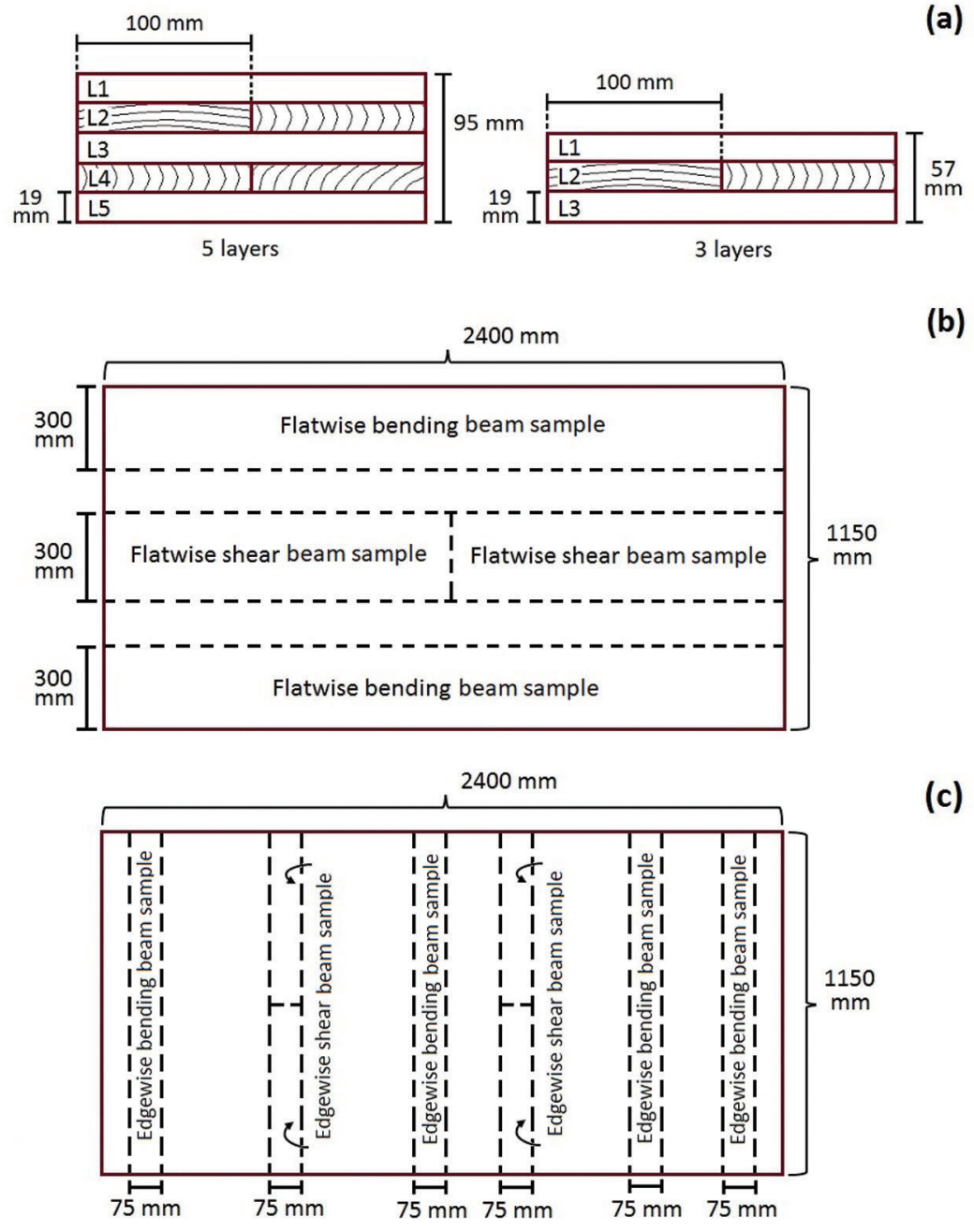

(b)

(c)

Figure 1: Configurations of the 5- and 3-layer CLT panels (a) and the flatwise (b) and edgewise (c) sampling method used for the evaluation of the physical and mechanical properties. Adapted with permission from Moya et al. [35], Copyright (C) 2021, Springer Verlag

\subsection{Panel Sampling}

Sampling sought to obtain the largest quantity of specimens to comply with the specifications of the performance-rated cross-laminated timber standard in its denomination ANSI/APA PRG320-2012 [18]. Samples were obtained for density, water absorption (WA), moisture content (MC), flexure test (bending and shear), compression test and glue-line shear test, all in flatwise and edgewise orientations. From the CLT panels constructed for each layer configuration (3 and 5 layers) per species, 3 CLT panels were sampled to obtain the specimens for flatwise orientation (Fig. 1b) and 2 for edgewise orientation (Fig. 1c). The sections of the CLT panels not indicated in the figures were used for the specimens in density, WA, MC and glue-line shear tests. 


\subsection{Delamination and Physical Properties}

The physical properties evaluated were density, water absorption (WA), and moisture content (MC). A total of 40 specimens ( 2 species $\times 2$ layers configurations $\times 10$ samples) were used, which were $70 \mathrm{~mm}$ wide $\times 100 \mathrm{~mm}$ long $\times$ thickness of the respective CLT panel. The density was calculated as the correlation between the weight and the volume (length, width and thickness) of the samples. As for MC and WA the standards ASTM D4442 [36] and ASTM D1037 [37] respectively, were used. Accordingly, to determine the WA, Eq. (1) proposed by Mohd Yusof et al. [26] was employed.

$\% W A=\frac{W_{2}-W_{1}}{W_{1}} \times 100$

where: $\mathrm{W}_{1}=$ mass $(\mathrm{g})$ of the test sample before immersion (the original dry weight); $\mathrm{W}_{2}=$ mass $(\mathrm{g})$ of the test sample after immersion.

For the delamination test 36 specimens $(2$ species $\times 2$-layer configuration $\times 9$ samples $)$ were used, each measuring $75 \mathrm{~mm}$ wide $\times 120 \mathrm{~mm}$ long $\times$ thickness of the respective CLT panel. Before applying the Cyclic Delamination Test [38] an evaluation was performed to discard and mark the open glue lines and measure the length of the closed glue lines. Next, procedure AITC T110 [38] was applied for the cyclic delamination test; the initially closed glue lines were evaluated and the length of the opening by delamination was measured to calculate the total delamination (Eq. (2)).

$\%$ Delamination $_{\text {total }}=\frac{l_{\text {tot }, \text { delam }}}{l_{\text {tot }, \text { glueline }}} \times 100$

where: $1_{\text {tot,delam }}=$ total delamination length in $\mathrm{mm}$ and $\mathrm{l}_{\text {tot,glueline }}=$ sum of the perimeters of all glue lines in a delaminated specimen.

\subsection{Mechanical Properties}

The mechanical properties evaluated were flexure test in flatwise and edgewise orientations, both of them in bending and shear condition, compression parallel to grain test in flatwise and edgewise orientations and glue line shear test. Following the standard for performance-rated cross-laminated timber in its denomination ANSI/APA PRG320-2012 [18], the standard ASTM D198 [39] was used to determine the flexure test in flatwise orientation in bending and shear conditions and the standard ASTM D4761-19 [40] for the flexure test in edgewise orientation in bending and shear conditions. Subsequently, tests were performed for 24 beams $(2$ species $\times 2$-layer configuration $\times 6$ samples $)$ size $300 \mathrm{~mm}$ wide $\times$ $2400 \mathrm{~mm}$ long $\times$ respective thickness of the CLT panel for flatwise direction in bending (Fig. 1b), and 24 beams $(2$ species $\times 2$-layer configuration $\times 6$ samples $)$ size $300 \mathrm{~mm}$ wide $\times 1150 \mathrm{~mm}$ long $\times$ respective thickness of the CLT panel for flatwise direction in shear (Fig. 1b). For edgewise trials, 32 beams $(2$ species $\times$ 2-layer configuration $\times 8$ samples $)$ measuring $75 \mathrm{~mm}$ wide $\times 1150 \mathrm{~mm}$ long $\times$ respective thickness of the CLT panel for bending and 32 beams $(2$ species $\times 2$-layer configuration $\times$ 8 samples) measuring $75 \mathrm{~mm}$ wide $\times 575 \mathrm{~mm}$ long $\times$ thickness for shear (Fig. 1c) were used.

As for compression parallel to the grain test, the ANSI/APA PRG320-2012 establishes the standard ASTM D4761 [40]. A total of 72 samples $(2$ species $\times 2$-layer configuration $\times 2$ orientations (flatwise and edgewise) $\times 9$ samples) of $70 \mathrm{~mm}$ wide $\times 480 \mathrm{~mm}$ long $\times$ respective thickness of the CLT panel were used. The glue-line shear test followed the procedure described in ASTM D905 [41] standard, using 120 samples $(2$ species $\times 2$-layer configuration $\times 2$ orientations (flatwise and edgewise $) \times 15$ samples $)$ de $63 \mathrm{~mm}$ long $\times 50 \mathrm{~mm}$ wide and $50 \mathrm{~mm}$ thick For both trials the samples were cut from the pieces of the CLT panels that remained after the flexure test. 


\subsection{Statistical Analysis}

One-way ANOVA was applied to the parameters of the physical (density, MC and WA), delamination and mechanical properties (MOE and Fc in compression and maximum stress in glue-line shear). The Tukey test was used to test the mean difference at a level of significance of $P<0.01$ per species per CLT panel layer. The SAS 8.1 statistics program for Windows (SAS Institute Inc., Cary, USA) was used to carry out the analyses.

\section{Results}

\subsection{Physical Properties}

Tab. 2 presents the values of density, WA and MC obtained per species and type of CLT panel. No differences in density, and WA and were observed between the configurations ( 3 and 5 layers) of CLT panels for the same species, but differences were observed in delamination. As for MC, the CLT panels of $T$. grandis showed no differences, but in the case of G. arborea wood, 3-layer CLT panels presented higher MC than 5-layer CLT panels. Regarding the differences between the species, CLT panels of T. grandis presented greater density, lower MC, slightly higher values of WA and slightly lower values of delamination.

Table 2: Density and moisture content parameters for the CLT panels of the two species

\begin{tabular}{llll}
\hline \multirow{2}{*}{ Species } & Physical property & \multicolumn{2}{c}{ Configurations } \\
\cline { 3 - 4 } & & 3-layer CLT panels & 5-layer CLT panels \\
\hline \multirow{2}{*}{ G. arborea } & Density $\left(\mathrm{g} / \mathrm{cm}^{3}\right)$ & $0.48^{\mathrm{A}}(0.45-0.51)$ & $0.49^{\mathrm{A}}(0.46-0.52)$ \\
& Moisture content (\%) & $12.34^{\mathrm{A}}(10.85-13.79)$ & $10.93^{\mathrm{B}}(9.39-12.30)$ \\
& Water absorption (\%) & $8.61^{\mathrm{A}}(6.90-10.60)$ & $8.12^{\mathrm{A}}(5.25-10.82)$ \\
& Delamination (\%) & $53.25^{\mathrm{A}}(8.93-93.53)$ & $66.36^{\mathrm{B}}(18.70-88.34)$ \\
\multirow{3}{*}{ grandis } & Density $\left(\mathrm{g} / \mathrm{cm}^{3}\right)$ & $0.60^{\mathrm{A}}(0.57-0.63)$ & $0.60^{\mathrm{A}}(0.57-0.63)$ \\
& Moisture content (\%) & $10.13^{\mathrm{A}}(9.45-10.91)$ & $10.21^{\mathrm{A}}(9.05-11.68)$ \\
& Water absorption (\%) & $8.90^{\mathrm{A}}(6.08-10.76)$ & $9.36^{\mathrm{A}}(7.73-12.37)$ \\
& Delamination (\%) & $51.39^{\mathrm{A}}(16.24-100.00)$ & $61.98^{\mathrm{B}}(29.42-88.68)$ \\
\hline
\end{tabular}

Note: Different letters between configurations means that there are statistical differences $(P$-value $<0.05)$. Values in parentheses correspond to minimum and maximum values.

\subsection{Flexure Test in Flatwise and Edgewise Direction}

CLT panels of $T$. grandis wood presented the highest values concerning CLT panels of G. arborea wood in the 3 parameters evaluated (Tab. 3). In the flexure tests of the CLT panels for both species, flatwise and edgewise, the 5-layer CLT panels presented values of bending stiffness (EI) statistically superior to the values of the 3-layer CLT panels. Conversely, the values of bending stress $(\mathrm{Fb})$ of the 3-layer CLT panels presented higher means than those of the 5-layer CLT panels (Tab. 3). As for average values of shear stress in bending (Fv), for both species in flatwise orientation, the 3-layer CLT panels presented values statistically superior to those of the 5-layer CLT panels. In edgewise orientation no statistical differences were observed between the number of layers composing the CLT panels (Tab. 3).

The load $v s$. deflection curves were made to illustrate the differences regarding the flexure test (Fig. 2). Flatwise orientation tests presented greater loads than edgewise orientation trials. In addition, flexure in shear tests (flatwise and edgewise) presented greater loads (Fig. 2b) and lower deflections relative to bending (Fig. 2d). Moreover, flatwise bending curves showed that 5-layer CLT panels presented greater loads 
concerning 3-layer CLT panels for both species (Figs. 2a and 2c). Conversely, flatwise shear curves showed that 3-layer CLT panels presented greater loads compared to 5-layer CLT panels in both species (Figs. 2b and $2 \mathrm{~d})$. As for edgewise bending and shear curves, a similar behavior was observed in flatwise bending, where 5-layer CLT panels in both species presented loads greater than in 3-layer CLT panels (Figs. 2c and 2d). In all the analysed curves (flatwise and edgewise bending and shear), both types of CLT panels of $T$. grandis wood presented greater loads than in panels of G. arborea wood (Fig. 2).

Table 3: Flexure test parameters for the 3- and 5-layer CLT panels of the two species

\begin{tabular}{llllll}
\hline Species & CLT orientation & $\begin{array}{l}\text { CLT panel } \\
\text { configuration }\end{array}$ & $\begin{array}{l}\text { EI } \\
\left(\mathrm{N}-m^{2} \times 10^{10}\right)\end{array}$ & $\begin{array}{l}\text { Fb } \\
(\mathrm{MPa})\end{array}$ & $\begin{array}{l}\text { Fv } \\
(\mathrm{MPa})\end{array}$ \\
\hline G. arborea & \multirow{2}{*}{ Flatwise } & 3-layers & $3.79^{\mathrm{B}}(0.27)$ & $18.26^{\mathrm{A}}(5.30)$ & $2.44^{\mathrm{A}}(0.36)$ \\
& & 5-layers & $13.30^{\mathrm{A}}(1.55)$ & $11.78^{\mathrm{B}}(1.93)$ & $1.03^{\mathrm{B}}(0.21)$ \\
& \multirow{2}{*}{ Edgewise } & 3-layers & $0.51^{\mathrm{B}}(1.41)$ & $23.40^{\mathrm{A}}(5.53)$ & $1.75^{\mathrm{A}}(0.50)$ \\
& & 5-layers & $1.05^{\mathrm{A}}(0.17)$ & $15.59^{\mathrm{B}}(4.31)$ & $2.06^{\mathrm{A}}(0.25)$ \\
T. grandis & \multirow{2}{*}{ Flatwise } & 3-layers & $5.57^{\mathrm{B}}(0.53)$ & $44.81^{\mathrm{A}}(8.82)$ & $3.53^{\mathrm{A}}(0.51)$ \\
& & 5-layers & $19.00^{\mathrm{A}}(0.70)$ & $26.77^{\mathrm{B}}(3.63)$ & $1.69^{\mathrm{B}}(0.24)$ \\
& \multirow{2}{*}{ Edgewise } & 3-layers & $0.62^{\mathrm{B}}(0.15)$ & $27.87^{\mathrm{A}}(8.76)$ & $2.63^{\mathrm{A}}(0.83)$ \\
& & 5-layers & $1.30^{\mathrm{A}}(0.30)$ & $17.19^{\mathrm{B}}(5.57)$ & $3.26^{\mathrm{A}}(0.48)$ \\
\hline Note: Values in parentheses correspond to the standard deviation. Different letters between configurations means that there are statistical differences
\end{tabular}

Note: Values in parentheses correspond to the standard deviation. Different letters between configurations means that there are statistical differences $(P$-value $<0.05)$
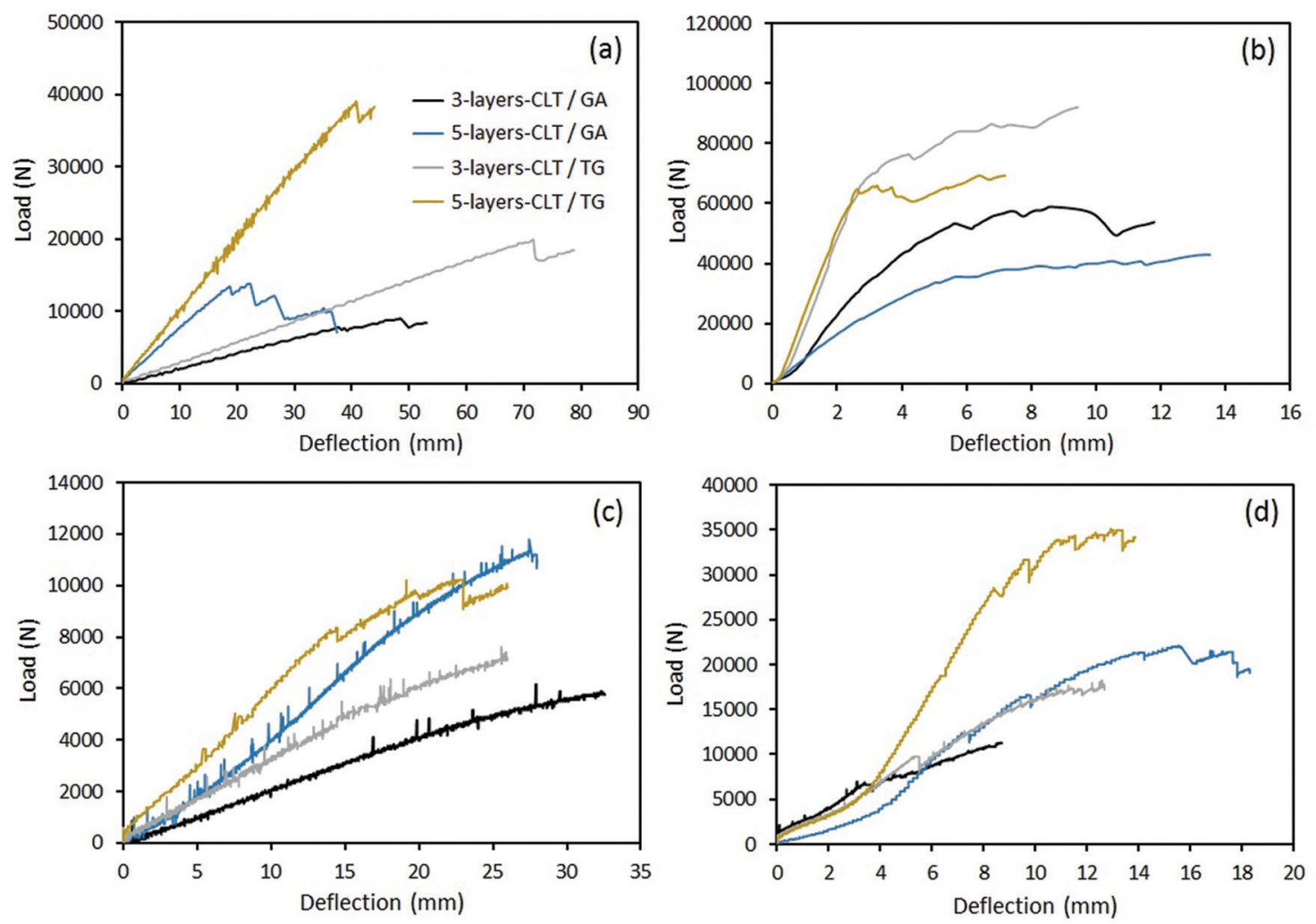

Figure 2: Load vs. deflection plots for flatwise bending (a) and shear (b), and edgewise bending (c) and shear (d) for the 3- and 5-layer CLT panels of both species 
Regarding the types of failure in the different layers of the beams of CLT panels in the flexure test in both orientations (flatwise and edgewise), the most frequent failures were due to tension (Fig. 3a) and delamination (Fig. 3b). The results in flexure tests in flatwise bending and shear of CLT panels of $G$. arborea were as follows.
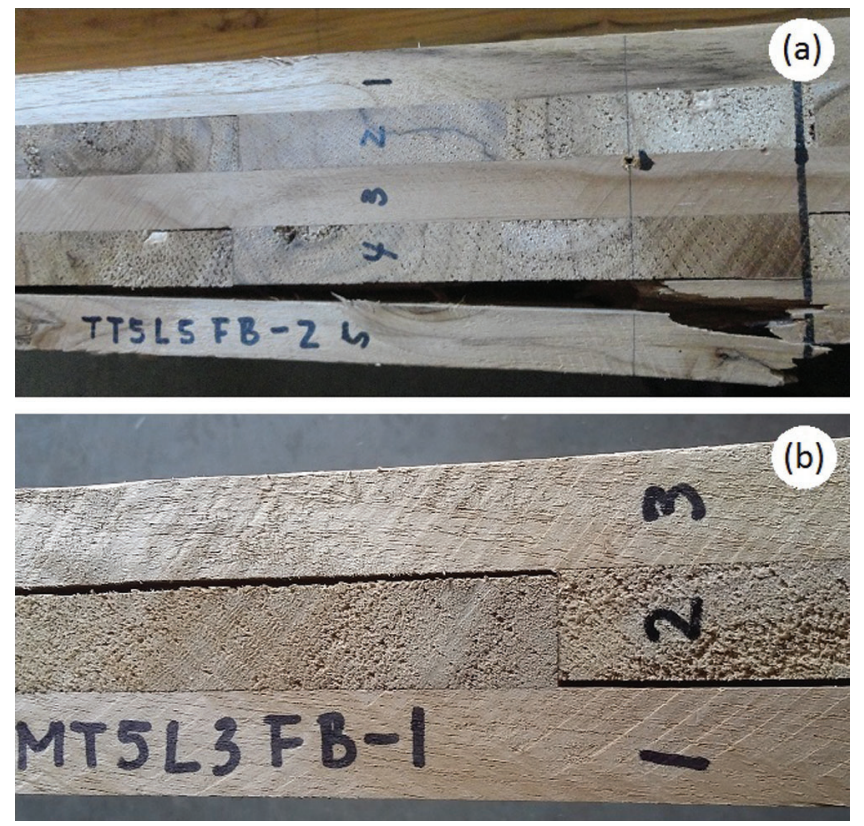

Figure 3: Failures in flexure test: tension (a) and delamination (b) for the 3- and 5-layer CLT panels of the two species

In the 3-layer CLT panels in flatwise bending in glue line L1 (glue line closest to loading application) $67 \%$ of the beams did not present failure; in glue line L2 (central glue line) $50 \%$ of the beams presented delamination and 50\% had no failures; in glue line L3 (glue line opposite to loading application) 50\% of the beams presented delamination failures and the other 50\% tension failures. In the case of 5-layer CLT panels, $67 \%, 83 \%$ and $100 \%$ of the beams showed no failure in glue lines L1, L3 and L4, respectively. In the glue line L2, 50\% of the beams presented delamination and 50\% no failure, while in glue line L5 (glue line opposite to loading application), $67 \%$ of the beams presented delamination failures.

- In the 3-layer CLT panels in flatwise shear, glue lines L1 and L2 presented 50\% delamination failure in beams and 50\% beams without failure, while glue line L3 presented a $100 \%$ tension failure in beams. In 5-layer CLT panels, in glue lines L1 and L3 over $67 \%$ of beams showed delamination; in L2 and L4, 67\% and 84\% of the beams showed no failure, respectively. Lastly, L5 presented tension failures in over $84 \%$ of the beams.

As for the beams tested in flatwise bending and shear in CLT panels fabricated with $T$. grandis wood:

- L1 in the 3-layer CLT panels in flatwise bending showed no failures in $100 \%$ of the tested beams tested; in L2, 50\% of the beams showed delamination and 50\% had no failures. In L3 over $66 \%$ of the beams showed tension failures. L1 and L3 in 5-layer CLT panels in flatwise bending presented failure in $100 \%$ and $84 \%$ of the beams, respectively; in L2 and L4, 50\% of the beams had 
delamination failures and $50 \%$ of the beams showed no failure. L5 presented tension failures in over $67 \%$ of the beams.

- In L1 in CLT panels in flatwise shear, $84 \%$ of the beams showed no failures. In L2, 50\% of the beams presented delamination failure and 50\% no failure; in L3, 84\% showed no failure. In 5-layer CLT panels, in L1, L3 and L5, 84\%, 67\% and $84 \%$ of the beams showed no failure, respectively; in L2, $50 \%$ of the beams presented delamination and 50\% showed no failure, while in L4 50\% presented delamination failure.

In edgewise bending and shear tests in CLT panels of G. arborea, beam failures were distributed as follows:

- In the 3-layer CLT panels in edgewise bending, over $63 \%$ of the beams did not present a failure in L1, $88 \%$ of the beams presented tension failure in L2 and $50 \%$ of the beams presented failure due to delamination in L3, whereas in the 5-layer CLT panels $88 \%$ of the beams did not present failure in $\mathrm{L} 1$ and $\mathrm{L} 5,75 \%$ of the beams presented tension failure in $\mathrm{L} 2,50 \%$ of the beams presented failure due to delamination in L3, 50\% showed tension failures and $50 \%$ no failure in L4.

- In the 3-layer CLT panels tested for edgewise shear, 38\% of the beams presented delamination failure and $38 \%$ tension failure in L1; $100 \%$ of the beams failed because of tension in L2 and $50 \%$ presented no failures in L3. In 5-layer CLT panels tested for edgewise shear, 63\% did not present failures in $\mathrm{L} 1$ and L3, 75\% presented tension failure in L2 and L4 and in L5 75\% did not present failure.

In edgewise bending and shear trials in CLT panels of $T$. grandis, beam failure distribution was as follows:

- In the 3-layer CLT panels tested for edgewise bending, 50\% of the beams showed no failures in L1; $100 \%$ and $63 \%$ presented tension failure in L2 and L3, respectively. As for 5-layer CLT panels, 50\% of the beams did not fail in L1, 88\% and $63 \%$ failed because of tension in L2 and L4, respectively, while 63\% did not fail in L3, and in L5 38\% presented tension failure and another 38\% did not fail.

- In 3-layer CLT panels tested for edgewise shear, $88 \%, 100 \%$ and $50 \%$ of the beams failed due to tension in L1, L2 and L3, respectively; whereas in 5-layer CLT panels, 50\%, 63\% and 75\% did not present failures in L1, L3 and L5, respectively; 75\% showed tension failure in L2, 50\% failed because of tension in L3 and 50\% did not present a failure in L4.

\subsection{Compression Parallel to Grain Test}

The values of MOE and module of rupture $(\mathrm{Fc})$ in the compression test, as well as in the flexure test flatwise, were higher than edgewise values (Fig. 4). Additionally, the average values of MOE and Fc in compression flatwise in 3-layer CLT panels were statistically higher than the obtained in 5-layer CLT panels, for both species (Figs. $4 \mathrm{a}$ and $4 \mathrm{~b}$ ), as opposed to the edgewise tests, where the average MOE and Fc of 5-layer CLT panels presented values statistically higher in 3-layer CLT panels of both species (Figs. 4a and 4b), except G. arborea panels, where no statistical difference appeared between CLT panels of 3 and 5 layers (Fig. 4b). In both trials (flatwise and edgewise) the average values of MOE and Fc in CLT panels of $T$. grandis were higher than in G. arborea (Fig. 4).

Three types of failure were observed in the flatwise and edgewise evaluation in the compression parallel to the grain test: shearing, splitting and crushing (Fig. 5):

- In 3-layer CLT panels of G. arborea wood tested for flatwise compression, 78\% of the beams presented crushing in L1 and L3 and 78\% presented splitting in L2. In 5-layer CLT panels, L1 presented $67 \%$ crushing, L2 and L4 presented $78 \%$ and $67 \%$ splitting, respectively; L3 presented $45 \%$ shearing and in L5 100\% of the beams showed shearing, crushing or no failure. 

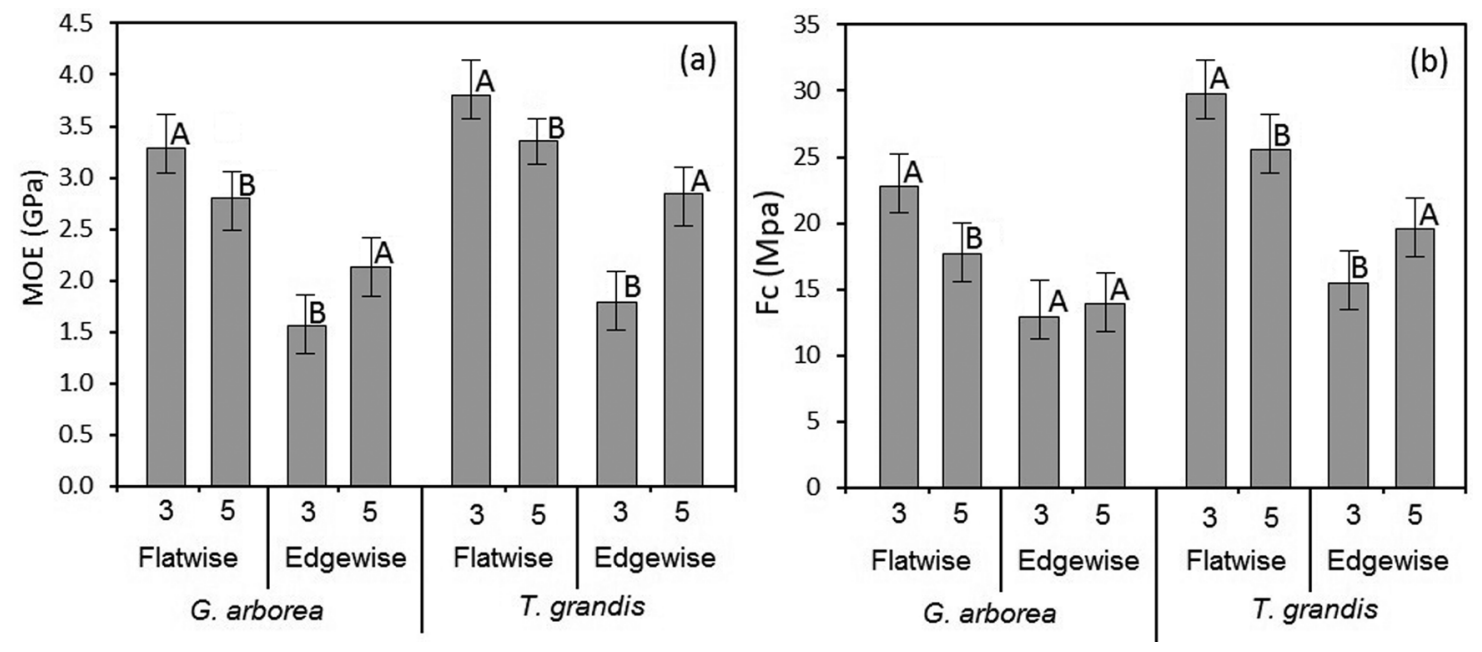

Figure 4: $\mathrm{MOE}$ (a) and $\mathrm{Fc}(\mathrm{b})$ parameters for compression parallel to the grain test for the 3- and 5-layer CLT panels of the two species. Note: Different letters between treatments means that there are statistical differences $(P$-value $<0.05)$ and the bars represents standard deviation
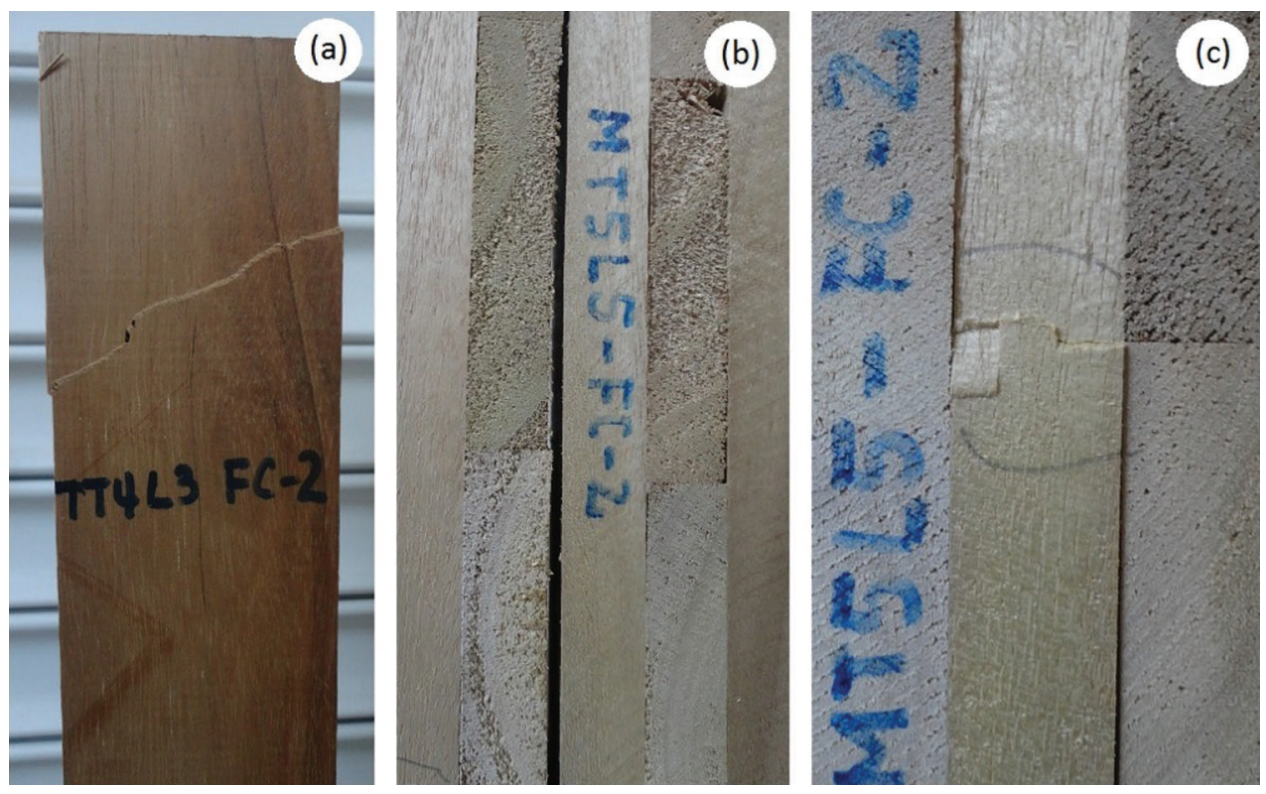

Figure 5: Failures in compression parallel to the grain test: shearing (a), splitting (b) and crushing (c) for the 3- and 5-layer CLT panels of the two species

- In 3-layer CLT panels of G. arborea tested edgewise, 55\% of the beams presented splitting failures in L1, 55\% crushing in L2 and 55\% showed no failures in L3; whereas 5-layer CLT panels presented $55 \%, 67 \%$ and $55 \%$ splitting failures in L1, L3 and L5, respectively; 55\% presented crushing in L2 and 33\% presented crushing failures and 33\% of the beams showed no failure in L4.

- In 3-layer CLT panels of T. grandis wood in flatwise compression, 55\% and $67 \%$ of the beams presented crushing failure in L1 and L3 and 45\% showed no failure in L2. In 5-layer CLT panels, $45 \%$ of the beams presented shearing failure and $45 \%$ crushing failure in L1, 55\% of the beams 
presented splitting, shearing and no failure in L2, L3 and L4, respectively, while 67\% showed no failure in L5.

- In 3-layer CLT panels of T. grandis wood in edgewise compression, 45\% and 55\% of the beams presented splitting failure in L1 and L3, respectively and 67\% crushing failure in L2. As regards 5-layer CLT panels, $88 \%$ and $55 \%$ of the beams presented no failures in L1 and L3, respectively; $45 \%$ presented crushing in L2 and L4 and 88\% presented splitting in L5.

\subsection{Glue-Line Shear Test}

No differences in maximum stress in glue-line shear were observed between the 3- and 5-layer CLT panels in any of the analyzed configurations (flatwise and edgewise) for both species (Tab. 4). In addition, CLT panels of $T$. grandis wood presented average values of maximum stress higher than the CLT panels of $G$. arborea wood.

Table 4: Maximum stress in glue-line shear for the 3- and 5- layer CLT panels of the two species

\begin{tabular}{llll}
\hline Specie & Direction loading application & CLT panel configurations & Maximum stress (MPa) \\
\hline G. arborea & Flatwise & 3 & $3.44^{\mathrm{A}}(1.53)$ \\
& & 5 & $2.45^{\mathrm{A}}(1.13)$ \\
& Edgewise & 3 & $2.30^{\mathrm{A}}(0.72)$ \\
& & 5 & $1.79^{\mathrm{A}}(1.09)$ \\
T. grandis & Flatwise & 3 & $4.19^{\mathrm{A}}(1.34)$ \\
& & 5 & $4.53^{\mathrm{A}}(1.52)$ \\
& Edgewise & 3 & $4.42^{\mathrm{A}}(1.49)$ \\
& & 5 & $3.31^{\mathrm{A}}(1.66)$ \\
\hline
\end{tabular}

Note: Values in parentheses correspond to the standard deviation. Different letters between configurations means that there are statistical differences $(P$-value $<0.05)$.

\section{Discussion}

CLT panels built with the two wood species reflect the density conditions of the wood before the manufacturing process. Although an increase in the mass of the panel should be expected from the amount of the adhesive used (approximately $0.6 \mathrm{~kg}$ due to a grammage of $200 \mathrm{~g} \mathrm{~m}^{-2}$ adhesive in approximately $3 \mathrm{~m}^{2}$ of panel area for each layer of timber), this increase in the density of 3-layer CLT and 5-layer CLT panels was not significant (Tab. 2). Furthermore, MC reflects the behavior of sawn wood. T. grandis wood presents uniform MC at the end of the drying process [30], while dried $G$. arborea wood is characterized by a great variability of MC [35]. Then, MC variability after drying probably influenced the differences in MC of G. arborea panels, the in higher MC in 3-layer CLT panels than in 5-layer CLT panels, hence the difference between these two configurations (Tab. 2).

Water absorption has direct effects on the mechanical and physical behaviour of the CLT panels and is related to the various wood polymers, cellulose, hemicellulose and lignin [42]. This study found no differences in the values of WA between the panels of both species and configurations (Tab. 2). The type of adhesive could have influenced this property [26].

Importantly, the percentage of delamination in CLT panels of T. grandis and G. arborea was above 50\% in both species, much greater than the percentage established by the EN16351:2015 standard (20\%) [43]. The characteristics of the glue-line of these same panels were analyzed previously by Moya et al. [35], who indicated that the panels presented critical delamination caused by problems in the manufacture [44] were 
probably associated with gluing problems [45]. The type of adhesive used could also be contributing to the high percentage of delamination; according to Corpataux et al. [46], the EPI adhesive is inapplicable in the tropics because of the prevailing moisture conditions of the geographic area, where the inappropriate performance of the glue-line causes delamination. Gathering from the results of the delamination test, the adhesive utilized in CLT panels of $T$. grandis and $G$. arborea was not the most suitable and efficient.

The most important factor in the variation of the mechanical properties of CLT panels is the density of each species, as these are positively correlated [47,48]. In this study, $T$. grandis wood presents a density of $0.64 \mathrm{~g} / \mathrm{cm}^{3}$, while G. arborea's density is of $0.48-0.49 \mathrm{~g} / \mathrm{cm}^{3}$. This difference is reflected in higher values of $\mathrm{EI}, \mathrm{Fb}$, and $\mathrm{Fv}$ in the flexure test (Tab. 3), lower deflection with greater load application (Fig. 2), higher MOE and Fc in compression parallel to the grain test (Fig. 4), and greater stress values in glue-line shear test (Tab. 4).

The comparison of the values of EI, Fb, and $\mathrm{Fv}$ in the flexure test (Tab. 3) with 3-layer CLT panels fabricated with white pine, red maple and white ash wood [49] or Pinus radiata wood [50] showed that 3-layer CLT panels of $T$. grandis and G. arborea wood present lower values of EI than those of the previous species. Meanwhile, the values of $\mathrm{Fb}$ and $\mathrm{Fv}$ of CLT panels of G. arborea wood also present lower values than those of white pine, red maple, white ash and Pinus radiata wood [45,46]; while the values of Fb and Fv of CLT panels of $T$. grandis wood surpass the values of Pinus radiata, white pine, red maple and white ash wood [45,46]. This behavior is related to with the density of the wood; the density of G. arborea wood is lower than in Pinus radiata, white pine, red maple, and white ash wood, whereas $T$. grandis wood presents a higher density relative to the previous species.

In both species, in the flexure test, 5-layer CLT panels presented values of El higher than in the 3-layer CLT panels in both orientations, flatwise and edgewise (Tab. 3). However, the values of Fb and Fv in 3-layer CLT panels offered better performance in rolling shear, since resistance to shear increases as the span-todepth decreases [51]. The span-to-depth in 3-layers, it was approximately 0.025 , and 0.042 in 5-layer panels.

Failure mechanisms in CLT panels either in flexure test or compression are unpredictable and unconventional and in most cases, occur close to the panel's maximum load [50]. In flexure, when the CLT panel is subjected to a load, it experiments shear stresses perpendicular to the grain inside the orthogonally oriented laminates [52] — a mechanism called "rolling shear stress" - causing tensile and delamination failures [51]. In this study, CLT panels of both species ( $G$. arborea and T. grandis) showed both types of failure (Figs. 3 and 5). In the flatwise bending flexure test, delamination occurred in lower layers (L3), located in the elongated section of the beam in 3-layer CLT panels. Contrariwise, in the shear flexure test, stress failure occurred in lower layers (L5), whereas in L4 it presented higher delamination. These results agree with the failure types reported by Navaratnam et al. [51] in 3- and 5-layer CLT panels in Pinus radiata.

Compression parallel to the grain reflects again the effect of higher density of the wood of $T$. grandis in relation to G. arborea wood since values of MOE and Fc are higher in T. grandis (Fig. 4). CLT panels have the potential for mid-rise buildings, where resistance to heavier vertical loads than in low-rise buildings is required [53]; therefore resistance to compression plays an important role [54]. Thus, CLT panels of $T$. grandis wood will perform better in compression than CLT panels of G. arborea wood.

During the compression test each layer acts independently [53]; therefore the resistance of CLT panels flatwise or edgewise is governed by the orientation of each layer. The configuration containing more layers parallel to load application flatwise presents greater resistance than edgewise in both species (Fig. 4). According to Oh et al. [53] the best performance in flatwise beams is given by CLT panels fabricated by gluing layers crosswise; hence, the layers of CLT cross to a loading direction will be stressed in perpendicular to the grain direction under compression. Resistance to compression perpendicular to the grain is approximately $10 \%$ of the resistance parallel to the grain, whereas the contribution of the 
transversal layers to resistance to compression is considered null $[53,54]$. Therefore, greater resistance is expected in testing with samples flatwise, as there is a greater number of longitudinal layers than edgewise.

Importantly, the highest values of MOE and Fc in CLT panels of both species were obtained in compression parallel to grain in the 3-layer configuration panels tested flatwise, whereas edgewise greater resistance was obtained in 5-layer panels for both MOE and Fc (Fig. 4). In compression parallel to the grain, as in the flexure test, the behavior is influenced by shear resistance between layers [55]. Lower resistance to transversal shear of CLT panels in the region of the glue line-known as rolling shear failure [56] - owed to the presence of transversal layers and low resistance to shear and rigidity [57]. Thus, in the flatwise test in 3-layer CLT panels, the number of layers influenced by shear is lower (1 out of 3, equivalent to $33.33 \%$ of the cross-section) than in 5-layer CLT panels ( 2 out of 5, equivalent to $40 \%$ of the cross-section), resulting in greater resistance to compression in 3-layer CLT panels. However, in the edgewise test these relationships are reversed; in 3-layer CLT panels, the number of shear-influenced layers ( 2 out of 3, equivalent to $66.67 \%$ of the cross-section) is greater than in 5-layer CLT panels ( 3 out of 5 , equivalent to $60 \%$ of the cross-section), resulting in greater resistance to compression in this last configuration.

Failures in compression parallel to grain (Fig. 5) have different causes [26]: the failure caused by shearing is presented in Fig. 5a and this failure is produced by maximum shear plane along $45^{\circ}$; splitting failure (Fig. 5b) is due to the low bonding integrity between wood and adhesive or shear resistance; and finally crushing failure (Fig. $5 \mathrm{c}$ ) is due to the weakness in compression and failure along the maximum compression line.

Additionally, layer orientation influences the production of each type of failure. Shearing and crushing are common when the strength is applied parallel to the layer (Figs. 5a and 5c). For example, in layers to which a parallel load was applied in the flatwise test, L1 and L3 in 3-layer CLT panels and L1, L3 and L5 in 5-layer CLT panels, in all cases over 55\% of all layers presented shearing and crushing, whereas if the layer received the load perpendicularly in the flatwise test, CLT panels would likely split (Fig. 5b).

In the evaluation of the mechanical properties in flexion and compression of the 3-and 5-layer CLT panels as established in Annex A PRG-320 standards [18], in both species and the two types of configuration the values of EI, Fb, Fv and Fc established for different softwood and hardwood species in North America in the categories of $\mathrm{E}$ and $\mathrm{V}$, are exceeded; thus, concerning compression and flexural properties of both $G$. arborea and $T$ grandis wood, both species can be considered suitable for CLT panel fabrication. In addition, the types of failures are similar to those reported for other species or are typical failures of such products.

The results of the glue-line shear test by Gaspar et al. [58] evidenced no significant differences between the 3-layer and 5-layer CLT panels, either flatwise and edgewise direction, as resulted here with the two species studied (Tab. 4); hence, adhesion is not affected by the number of layers used and adherence is conserved. This result does not mean that the strength applied in both panels was uniform in both configurations since no differences appeared between the 3- and 5-layer CLT panels. A slight difference occurs is in resistance according to species. A slight reduction in the values of maximum stress in G. arborea panels concerning T. grandis panels was observed (Tab. 4). Shear stress in the glue-line grows with the increasing density of the wood [59]. The density of $T$. grandis is higher than for $G$. arborea, therefore, greater resistance is present in the glue-line of $T$. grandis wood.

The differences in the two types of configurations (3- and 5-layer) of CLT panels and in the two species studied (CLT panels of $T$. grandis with higher properties than CLT panels of G. arborea) can determine the use conditions for each condition/species. When there is high structural demand in bending, like floors, 5layer CLT panels fabricated of $T$. grandis could be used. But if the use condition is less demanding of structural requirement, it is possible to use 3-layer CLT panels fabricated with G. arborea or T. grandis 
can be used. In this condition, using either species a determined configuration has no effect on stress in glueline shear due to the lack of difference between the configurations.

\section{Conclusion}

The results of the physical properties obtained show that the density values are within the range of the species commonly used in the manufacture of CLT panels. Moreover, adequate values of water absorption and mechanical properties were obtained.

The evaluation of the mechanical properties in bending and compression of the 3- and 5-layer CLT panels in the two species according to the Annex A PRG-320 standards surpass the values of EI, Fb, Fv, and Fc established for different softwood and hardwood species in North America in the E and V categories. In addition, the types of failures observed are similar to those reported for other species or are typical of such products.

In general, satisfactory behavior was observed in the glue line shear test. However, high levels of delamination were evidenced, which can be solved with the application of a more appropriate adhesive for the species and climate, or by studying pressure conditions in the manufacture of the CLT panels.

Acknowledgement: We thank the Vicerrectoría de Investigación y Extensión of the Instituto Tecnológico de Costa Rica for financing this research and the companies NovelTeak de Costa Rica S.A. and Maderas S\&Q 2005 S.A. for providing the raw material for this study. The authors thank María Teresa Vargas L. for translation into English.

Funding Statement: The funding was provided by Vicerrectoría de Investigación y Extensión, of the Instituto Tecnológico de Costa Rica.

Conflicts of Interest: The authors declare that they have no conflicts of interest to report regarding the present study.

\section{References}

1. Jeleč, M., Varevac, D., Rajčić, V. (2018). Cross-laminated timber (CLT) - A state of the art report. Journal of the Croatian Association of Civil Engineers, 70(2), 75-95. DOI 10.14256/JCE.2071.2017.

2. Lou, Z., Yuan, T., Wang, Q., Wu, X., Hu, S. et al. (2021). Fabrication of crack-free flattened bamboo and its macro-/micro-morphological and mechanical properties. Journal of Renewable Materials, 9(5), 959-977. DOI 10.32604/jrm.2021.014285.

3. Dolan, J. D., Wilson, A., Brandt, K., Bender, D. A., Wolcott, M. P. (2019). Structural design process for estimating cross-laminated timber use factors for buildings. BioResources, 14(3), 7247-7265. DOI 10.15376/ biores.14.3.7247-7265.

4. Espinoza, O., Buehlmann, U. (2018). Cross-laminated timber in the USA: Opportunity for hardwoods? Current Forestry Reports, 4(1), 1-12. DOI 10.1007/s40725-018-0071-x.

5. Hindman, D. P., Bouldin, J. C. (2015). Mechanical properties of southern pine cross-laminated timber. Journal of Materials in Civil Engineering, 27(9), 4014251. DOI 10.1061/(ASCE)MT.1943-5533.0001203.

6. Espinoza, O., Trujillo, V. R., Laguarda Mallo, M. F., Buehlmann, U. (2016). Cross-laminated timber: Status and research needs in Europe. BioResources, 11(1), 281-295. DOI 10.15376/biores.11.1.281-295.

7. Li, X., Ashraf, M., Subhani, M., Ghabraie, K., Li, H. et al. (2021). Withdrawal resistance of self-tapping screws inserted on the narrow face of cross laminated timber made from Radiata Pine. Structures, 31(2), 1130-1140. DOI 10.1016/j.istruc.2021.02.042.

8. Li, X., Ashraf, M., Subhani, M., Kremer, P., Li, H. et al. (2021). Rolling shear properties of cross-laminated timber (CLT) made from Australian Radiata Pine-An experimental study. Structures, 33(3), 423-432. DOI 10.1016/j. istruc.2021.04.067. 
9. Li, X., Ashraf, M., Subhani, M., Kremer, P., Kafle, B. et al. (2020). Experimental and numerical study on bending properties of heterogeneous lamella layups in cross laminated timber using Australian Radiata Pine. Construction and Building Materials, 247(9), 118525. DOI 10.1016/j.conbuildmat.2020.118525.

10. Giaccu, G. F., Meloni, D., Valdès, M., Fragiacomo, M. (2017). Dynamic determination of the modulus of elasticity of maritime pine cross-laminated panels using vibration methods. WIT Transactions on Ecology and the Environment, 226, 571-579. DOI 10.2495/SDP170501.

11. Izzi, M., Casagrande, D., Bezzi, S., Pasca, D., Follesa, M. et al. (2018). Seismic behaviour of cross-laminated timber structures: A state-of-the-art review. Engineering Structures, 170(3), 42-52. DOI 10.1016/j. engstruct.2018.05.060.

12. Jing, L., Xu, H., Guo, X., Di, Y. (2017). Technical advantages and limitations of cross-laminated timber high-rise buildings. Urbanism and Architecture, 17(7), 7-14.

13. Klippel, M., Schmid, J. (2017). Design of cross-laminated timber in fire. Structural Engineering International, 27(2), 224-230. DOI 10.2749/101686617X14881932436096.

14. Cappellazzi, J., Konkler, M. J., Sinha, A., Morrell, J. J. (2020). Potential for decay in mass timber elements: A review of the risks and identifying possible solutions. Wood Material Science \& Engineering, 15(6), 351-360. DOI 10.1080/17480272.2020.1720804.

15. Muszynski, L., Hansen, E., Fernando, S., Schwarzmann, G., Rainer, J. (2017). Insights into the global crosslaminated timber industry. Bioproducts Business, 2(8), 77-92. DOI 10.22382/bpb-2017-008.

16. Cherry, R., Manalo, A., Karunasena, W., Stringer, G. (2019). Out-of-grade sawn pine: A state-of-the-art review on challenges and new opportunities in cross laminated timber (CLT). Construction and Building Materials, 211(6), 858-868. DOI 10.1016/j.conbuildmat.2019.03.293.

17. Pei, S., van de Lindt, J. W., Popovski, M., Berman, J. W., Dolan, J. D. et al. (2016). Cross-laminated timber for seismic regions: Progress and challenges for research and implementation. Journal of Structural Engineering, 142(4), E2514001. DOI 10.1061/(ASCE)ST.1943-541X.0001192.

18. APA (2018). ANSI/APA PRG 320: Standard for performance rated cross-laminated timber. Tacoma, USA: American National Standard.

19. Fink, G., Kohler, J., Brandner, R. (2018). Application of European design principles to cross laminated timber. Engineering Structures, 171(11), 934-943. DOI 10.1016/j.engstruct.2018.02.081.

20. Adhikari, S., Quesada, H., Bond, B., Hammett, T. (2020). Potential of hardwood lumber in cross laminated timber in North America: A CLT manufacturer's perspective. Mass Timber Construction Journal, 3(1), 1-9.

21. Corpataux, L., Okuda, S., Kua, H. W. (2020). Panel and plate properties of Cross-laminated timber (CLT) with tropical fast-growing timber species in compliance with Eurocode 5. Construction and Building Materials, 261(5-6), 119672. DOI 10.1016/j.conbuildmat.2020.119672.

22. Latib, H. A., Cheong, L. W., Halis, R., Mohamad Kasim, M. R., Yi, L. Y. et al. (2019). The prospects of wooden building construction in Malaysia: Current state of affairs. BioResources, 14(4), 9840-9852. DOI 10.15376/ biores.14.4.9840-9852.

23. Oliveira, G. L., de Oliveira, F. L., Brazolin, S. (2018). Wood preservation for preventing biodeterioration of cross laminated timber (CLT) panels assembled in tropical locations. Procedia Structural Integrity, 11(76), 242-249. DOI 10.1016/j.prostr.2018.11.032.

24. Nunes, G., de Melo Moura, J. D., Güths, S., Atem, C., Giglio, T. (2020). Thermo-energetic performance of wooden dwellings: Benefits of cross-laminated timber in Brazilian climates. Journal of Building Engineering, 32(13), 101468. DOI 10.1016/j.jobe.2020.101468.

25. Adnan, N. A., Md Tahir, P., Husain, H., Lee, S. H., Anwar Uyup, M. K. et al. (2020). Effect of ACQ treatment on surface quality and bonding performance of four Malaysian hardwoods and cross laminated timber (CLT). European Journal of Wood and Wood Products, 1-15. DOI 10.1007/s00107-020-01609-7.

26. Yusof, N. M., Tahir, P. M., Lee, S. H., Khan, M. A., James, R. M. S. (2019). Mechanical and physical properties of Cross-Laminated Timber made from Acacia mangium wood as function of adhesive types. Journal of Wood Science, 65(1), 20-32. DOI 10.1186/s10086-019-1799-z. 
27. Byeon, J. W., Kim, T. H., Yang, J. K., Byeon, H. S., Park, H. M. (2018). Static bending performances of crosslaminated wood panels made with tropical and temperate woods. Journal of the Korean Wood Science and Technology, 46(6), 726-734. DOI 10.5658/WOOD.2018.46.6.726.

28. Liao, Y., Tu, D., Zhou, J., Zhou, H., Yun, H. et al. (2017). Feasibility of manufacturing cross-laminated timber using fast-grown small diameter eucalyptus lumbers. Construction and Building Materials, 132(1), 508-515. DOI 10.1016/j.conbuildmat.2016.12.027.

29. Kollert, W., Walotek, J. P. (2017). Economics, production, markets and trade. In: Kollert, W., Kleine, M. (Eds.), IUFRO world series volume 36: The global teak study: Analysis, evaluation and future potential of teak resources. 1st ed., pp. 85-93. Vienna, Austria: International Union of Forest Research Organizations.

30. Moya, R., Berrocal, A., Rodriguez-Solis, M., Muñoz, F. (2017). Effect of steam-drying treatment on moisture content, drying rate, color, and drying defects in juvenile wood of Tectona grandis from fast-growth plantations. Drying Technology, 35(15), 1832-1842. DOI 10.1080/07373937.2017.1280503.

31. Rivera-Tenorio, M., Moya, R. (2019). Stress, displacement joints of Gmelina arborea and Tectona grandis wood with metal plates, screws and nails for use in timber truss connections. Cerne, 25(2), 172-183. DOI 10.1590/ 01047760201925022641.

32. Rivera-Tenorio, M., Moya, R., Navarro-Mora, Á. (2020). Wooden trusses using metal plate connections and fabricated with Gmelina arborea, Tectona grandis and Cupressus lusitanica timber from forest plantations. Journal of the Indian Academy of Wood Science, 17(2), 183-194. DOI 10.1007/s13196-020-00271-z.

33. Leiva-Leiva, T., Moya, R., Navarro-Mora, A. (2018). Model calibration of prefabricated timber wall frames made of Hieronyma alchorneoides and Gmelina arborea timber using nail and screw fasteners. Drvna Industrija, 69(1), 3-12. DOI 10.5552/drind.2018.1722.

34. Triwibowo, D., Sejati, P. S., Gopar, M., Sudarmanto, S., Akbar, F. et al. (2020). Karakteristik Cross Laminated Timber (CLT) dari Kayu Jati Platinum Hasil Penjarangan dan Limbah Batang Kelapa Sawit (Characteristic of cross laminated timber (CLT) from thinned platinum teak and oil palm stem waste). Jurnal Sylva Lestari, 8(3), 340. DOI 10.23960/js138340-350.

35. Moya, R., Tenorio, C., Muñoz, F. (2021). Ultrasound velocity mapping to evaluate gluing quality in CLT panels from plantation wood species. Wood Science and Technology, 55(3), 681-696. DOI 10.1007/s00226-021-01273-x.

36. ASTM (2016). Standard test methods for direct moisture content measurement of wood and wood-based materials. Annual book of ASTM standards, vol. 4, no. 10, D4442-16. 8. Pennsylvania: ASTM International, West Conshohocken. DOI 10.1520/D4442-16.

37. ASTM (2020). Standard test methods for evaluating properties of wood-based fiber and particle panel materials. Annual book of ASTM standards, vol. 4, no. 10D1037-12. 12. Pennsylvania: ASTM International, West Conshohocken. DOI 10.1520/D1037-12R20.

38. AITC (2007). Test methods for structural glued laminated timber, T110-Cycli, pp. 19-21. Centennial, Colorado, USA.

39. ASTM (2014). Standard test methods of static tests of lumber in structural sizes. ASTM, D198-09, pp. 1-27. Pennsylvania: ASTM International, West Conshohocken. DOI 10.1520/D0198-15.

40. ASTM (2019). Standard test methods for mechanical properties of lumber and wood-base structural material. ASTM, D4761-19, 10. Pennsylvania: ASTM International, West Conshohocken. DOI 10.1520/D4761-19.

41. ASTM (2013). Standard test method for strength properties of adhesive bonds in shear by compression loading. Annual Book of ASTM Standards. vol. 4, no. 10, ASTM D905-5, 13. Pennsylvania: ASTM International, West Conshohocken. DOI 10.1520/D0905-08R21.

42. Rindler, A., Vay, O., Hansmann, C., Müller, U. (2017). Dimensional stability of multi-layered wood-based panels: A review. Wood Science and Technology, 51(5), 969-996. DOI 10.1007/s00226-017-0940-7.

43. CEN (2015). Timber structures—Cross laminated timber—Requirement. EN 16351:2015, 15. Brussels, Belgium: Euroean Committee for Standardisation.

44. Nairn, J. A. (2017). Cross laminated timber properties including effects of non-glued edges and additional cracks. European Journal of Wood and Wood Products, 75(6), 973-983. DOI 10.1007/s00107-017-1202-y. 
JRM, 2022, vol.10, no.1

45. Brandner, R., Flatscher, G., Ringhofer, A., Schickhofer, G., Thiel, A. (2016). Cross laminated timber (CLT): Overview and development. European Journal of Wood and Wood Products, 74(3), 331-351. DOI 10.1007/ s00107-015-0999-5.

46. Corpataux, L., Muthukrishnan, S., Kua, H., Okuda, S., Wei, K. H. (2018). Cross-laminated timber with renewable, fast-growing tropical species in southeast Asia. 2018 World Conference on Timber Engineering, pp. 1-10. Seoul, Korea.

47. Saavedra Flores, E. I., Ajaj, R. M., Dayyani, I., Chandra, Y., Das, R. (2016). Multi-scale model updating for the mechanical properties of cross-laminated timber. Computers \& Structures, 177(2), 83-90. DOI 10.1016/j. compstruc.2016.08.009.

48. Brandner, R., Dietsch, P., Dröscher, J., Schulte-Wrede, M., Kreuzinger, H. et al. (2017). Cross laminated timber (CLT) diaphragms under shear: Test configuration, properties and design. Construction and Building Materials, 147(5), 312-327. DOI 10.1016/j.conbuildmat.2017.04.153.

49. Crovella, P., Smith, W., Bartczak, J. (2019). Experimental verification of shear analogy approach to predict bending stiffness for softwood and hardwood cross-laminated timber panels. Construction and Building Materials, 229, 116895. DOI 10.1016/j.conbuildmat.2019.116895.

50. Navaratnam, S., Christopher, P. B., Ngo, T., Le, T. V. (2020). Bending and shear performance of Australian Radiata pine cross-laminated timber. Construction and Building Materials, 232(4), 117215. DOI 10.1016/j. conbuildmat.2019.117215.

51. Navaratnam, S., Ngo, T., Christopher, P., Linforth, S. (2020). The use of digital image correlation for identifying failure characteristics of cross-laminated timber under transverse loading. Measurement, 154(4), 107502. DOI 10.1016/j.measurement.2020.107502.

52. Wang, Z., Zhou, J., Dong, W., Yao, Y., Gong, M. (2018). Influence of technical characteristics on the rolling shear properties of cross laminated timber by modified planar shear tests. Maderas: Ciencia y Tecnologia, 20(3), 469478. DOI 10.4067/S0718-221X2018005031601.

53. Oh, J. K., Lee, J. J., Hong, J. P. (2015). Prediction of compressive strength of cross-laminated timber panel. Journal of Wood Science, 61(1), 28-34. DOI 10.1007/s10086-014-1435-x.

54. Wiesner, F., Bisby, L. (2019). The structural capacity of laminated timber compression elements in fire: A metaanalysis. Fire Safety Journal, 107(1), 114-125. DOI 10.1016/j.firesaf.2018.04.009.

55. Steiger, R., Gülzow, A., Czaderski, C., Howald, M. T., Niemz, P. (2012). Comparison of bending stiffness of crosslaminated solid timber derived by modal analysis of full panels and by bending tests of strip-shaped specimens. European Journal of Wood and Wood Products, 70(1-3), 141-153. DOI 10.1007/s00107-011-0521-7.

56. Gong, Y., Liu, F., Tian, Z., Wu, G., Ren, H. et al. (2019). Evaluation of mechanical properties of cross-laminated timber with different lay-ups using Japanese larch. Journal of Renewable Materials, 7(10), 941-956. DOI $10.32604 / \mathrm{jrm} .2019 .07354$.

57. Franzoni, L., Lebée, A., Lyon, F., Foret, G. (2016). Influence of orientation and number of layers on the elastic response and failure modes on CLT floors: Modeling and parameter studies. European Journal of Wood and Wood Products, 74(5), 671-684. DOI 10.1007/s00107-016-1038-x.

58. Gaspar, F., Cruz, H., Gomes, A. (2018). Evaluation of glue line shear strength of laminated timber structures using block and core type specimens. European Journal of Wood and Wood Products, 76(2), 413-425. DOI 10.1007/ s00107-017-1217-4.

59. Yusoh, A. S., Tahir, P. M., Uyup, M. K. A., Lee, S. H., Husain, H. (2020). Effect of wood species, clamping pressure and glue spread rate on the bonding properties of cross-laminated timber (CLT) manufactured from tropical hardwoods. Construction and Building Materials, 273(3), 121721. DOI 10.1016/j. conbuildmat.2020.121721. 